\title{
ОРГАНІЗАЦІЙНО-ПРАВОВЕ ВИВЧЕННЯ ТА ВИКОНАННЯ АДМІНІСТРАТИВНИМ ПЕРСОНАЛОМ ВИШІВ ЛІЦЕНЗІЙНИХ УМОВ ЩОДО ПРОВАДЖЕННЯ ОСВІТНЬОЇ ДІЯЛЬНОСТІ В УКРАЇНІ ПІД ЧАС ПАНДЕМІї НА COVID-19
}

\section{ORGANIZATIONAL AND LEGAL STUDY AND IMPLEMENTATION BY ADMINISTRATIVE STAFF OF HIGHER EDUCATION OF LICENSING CONDITIONS FOR EDUCATIONAL ACTIVITIES IN UKRAINE DURING COVID-19 PANDEMIC}

Ігор Гайдучок (Ihor Hayduchok), доктор медичних наук, в.о. професора, ТзОВ «Львівський медичний інститут», Львів, Україна; Валерій Шаповалов (Valerii Shapovalov), доктор фармацевтичних наук, професор, ТзОВ «Львівський медичний інститут», Львів, Україна; Валентин Шаповалов (Valentyn Shapovalov), доктор фармацевтичних наук, професор, Адвокатське об’єднання «Апофеоз», Харків, Україна

Abstract. Organizational and legal studies and implementation of licensing conditions and regulations on the conduct of educational activities in Ukraine during the pandemic at COVID-19 were carried out by administrative staff. The necessity of further improvement of the system of licensing of educational activity is substantiated. The expediency of maintaining the licensing of educational activities for each specialty at each level of higher education and the transition to licensing of educational activities only at the levels. An alternative to creating separate requirements for each specialty, which is more in line with the current Law on Higher Education, has been proposed. But this is problematic in terms of feasibility and, obviously, contradicts the course of deregulation and the practices that exist in the European Higher Education Area. Another alternative is the transition to licensing educational activities in the fields of knowledge. In the more (but not very) long-term perspective, more conceptual issues need to be addressed: where is the limit of appropriate state intervention in the activities of the Free Economic Zone; what exactly needs to be licensed; which requirements may be useful and which will only hinder the development of higher education institutions. Further organizational and legal research on the compliance of administrative staff with higher licensing conditions and regulations for educational activities in Ukraine during the pandemic at COVID-19 continues.

Keywords: COVID-19, educational activities, licensing, institutions of higher education, normative activities.

Вступ. В сучасних умовах у всіх регіонах країни поширюється пандемія на COVID-19 (нові штами «Дельта», «Омікрон»), що потребує удосконалення організаційно-правової роботи органів державної влади і місцевого самоврядування [1-4], закладів охорони здоров'я (комунальних неприбуткових підприємств) [5, 6] і аптек [7-9] щодо щеплення населення відповідними вакцинами, проведення вчасної ревакцинації [10-12], забезпечення життєво необхідними лікарськими засобами (Л3) $[13,14]$, надання медичної допомоги хворим у відповідності до МКХ-11 [15-17], які перебувають в амбулаторних та стаціонарних умовах, як заходу, що створює колективний імунітет громадян України, який базується на Конституції України, принципах медичного i фармацевтичного права [18-26].

Разом 3 тим слід вказати, що за даними МО3 України [27], за добу 05.02.2022 p. в Україні зафіксовано 27851 новий підтверджений випадок 
коронавірусної хвороби COVID-19 (з них дітей - 2597, медпрацівників - 431), найбільше в областях: Одеська (2788), м. Київ (2298), Хмельницька (2070), Харківська (1897), Житомирська (1773), Сумська (1612), Львівська (1572), Дніпропетровська (1289). Старт вакцинації від COVID-19 в Україні відбувся 24.02.2021 р., проведено усього 30699982 щеплень. МОЗ України нагадує про виконання трьох простих правил протиепідемічної безпеки: дотримання дистанції, носіння маски та користування санітайзерами.

Статистика щеплень від коронавірусу COVID-19 в Україні на 05.02.2022 p. [28]: повністю вакциновано 35,89\% громадян (повністю вакииновано - загальна кількість осіб, які отримали всі дози, що встановлені протоколом вакцинації). Найбільше щеплень в: м. Київ (62,07\%), Київська (46,38\%); Полтавська (44,98\%), Дніпропетровська $(43,20 \%)$, Черкаська $(41,91)$, Харківська $(40,24 \%)$, Сумська $(41,05)$, Чернігівська $(39,67 \%)$, Львівська $(39,09 \%)$ області. Найменше щеплень: Луганська (13,38 \%), Донецька (15,02\%), Закарпатська $(24,49)$, Івано-Франківська (30,10\%) області.

Пандемія коронавірусної хвороби підштовхнула розвиток інформаційних технологій в освітній діяльності. Саме розвиток інтернету вніс зміни не лише в маркетингові можливості компаній, вишів, закладів охорони здоров'я, аптек щодо просування, а й у сам процес надання послуг. Сьогодні більшість провідних університетів пропонують великий спектр освітніх курсів онлайн, а тому галузева конкуренція стає глобальною. Іміджеві та ринкові позиції вишів формуються не лише в освітньому офлайн, але й інтернет-середовищі. Тому розвиток та стійкі ринкові позиції закладу вищої освіти (ЗВО) може забезпечити системна кропітка робота 3 маркетингового управління $3 \mathrm{BO}$ та його структурними підрозділами [29].

Організаційно-педагогічна тенденція розвитку дистанційної освіти в Україні пов'язана як з адаптацією уже існуючих навчальних планів, робочих програм, змісту навчальних дисциплін, систем контролю якості освіти, так і 3 розробкою нового дидактичного забезпечення на основі модульного підходу 3 використанням інформаційно-комп'ютерних технологій. Безумовно, що метод дистанційного навчання повністю не замінить традиційну освіту в аудиторії, де динаміка спілкування з викладачем, колективна робота студентів та соціальна динаміка надзвичайно важлива для навчального процесу [30].

Що стосується європейських чи американських університетів, то на їхніх сайтах наявна інформація про акредитацію, рейтинги та стратегію розвитку, а про ліцензії, як і про ліцензійні обсяги, жодної інформації не вдалось знайти [31]. Очевидно, лише в Україні у вигляді ліцензійних обсягів зберігся атавізм командної економіки, коли ЗВО централізовано встановлювались плани набору студентів на кожну спеціальність. Автори формулюють такі пропозиції: 1) скасувати квотування у сфері вищої освіти та дозволити ЗВО самостійно визначати обсяги здобувачів вищої освіти за спеціальностями, формами навчання, освітніми рівнями 3 дотриманням санітарних, технологічних та кадрових вимог; 2) вилучити поняття ліцензований обсяг у сфері вищої освіти 3 нормативних документів. Прогнозовані очікувані наслідки: ЗВО зможуть 
оперативніше реагувати на запити ринку праці; економія ресурсів; зменшення джерел корупційних дій [31].

Інформатизація системи охорони здоров'я $\epsilon$ визнаним фактом, уже оціненим медичною та фармацевтичною спільнотою, незворотнім процесом, що охоплюватиме все більше сторін діяльності медичної і фармацевтичної галузі [32]. Запровадження медичних інформаційних систем (МIC) потребує створення умов для підготовки медичних фахівців, здатних ефективно використовувати їх в повсякденній професійній діяльності, та розробки навчальних програм підготовки таких фахівців на додипломному та післядипломному рівні. Новітні інноваційні освітні технології (MIC) дають широкі можливості диференціації та індивідуалізації навчальної діяльності. Результат застосування МIC залежить не тільки від майстерності викладача, а й від мотивації студента до навчання. Разом 3 тим МІС пов'язані з підвищенням ефективності навчання й виховання та спрямовані на кінцевий результат освітнього процесу - підготовку висококваліфікованих медичних фахівців, здатних успішно освоювати i впроваджувати нові професійні та управлінські інновації, гнучко та динамічно реагувати на мінливі соціально-економічні умови; володіти високими моральними і громадянськими якостями в умовах інноваційного освітнього простору.

Освітня діяльність у сфері післядипломної освіти для осіб (лікарів, провізорів) з вищою освітою здійснюється ЗВО за наявності ліцензії. Рішення про видачу ліцензії приймає Міністерство освіти і науки України після розгляду заяви та документів, що підтверджують відповідність забезпечення освітнього процесу заявника ліцензійним умовам.

Мета. Організаційно-правове вивчення та виконання адміністративним персоналом вишів (ЗВО) ліцензійних умов і нормативно-правових актів щодо провадження освітньої діяльності в Україні під час пандемії на COVID-19.

Матеріали та методи дослідження. У роботі було проведено огляд нормативно-правових актів та директивно-розпорядчих документів з офіційного веб-порталу парламенту України «Законодавство України» 3 питань ліцензійних умов провадження освітньої діяльності, а також інших веб-порталів (понад 30). Для досягнення поставленої мети використовувалися методи нормативноправового, документального, ретроспективного, порівняльного, графічного та табличного аналізу.

Проведені дослідження $є$ фрагментом науково-дослідних робіт ТзОВ «Львівський медичний інститут» (ЛМІ) за темою «Удосконалення системи обігу ліків під час фармакотерапії на засадах доказової і судової фармації, організації, технології, біофармації та фармацевтичного права» (номер державної реєстрації 0120U105348, термін виконання 2021-2026), ХМАПО за темами «Удосконалення організаційно-правової процедури забезпечення ліками пацієнтів 3 позиції судової фармації, організації i управління фармацією» (номер державної реєстрації 0116U003137, термін виконання 2016-2020 рр.) та «Фармацевтичне та медичне право: інтегровані підходи до системи обігу ліків 3 позиції судової фармації та організації фармацевтичної справи» (номер державної реєстрації 
0121 U000031, термін виконання 2021-2026 pp.).

Результати дослідження та їх обгорнення. Сьогодення ставить перед учасниками ринку освітніх послуг серйозні виклики, які мають мобілізувати зусилля суспільства у напряму підвищення ефективності інвестицій у людський капітал як основи економічного заростання країни, збільшення іiі науковотехнічного потенціалу [33].

Національна стратегія розвитку освіти в Україні (затверджена Указом Президента України 25 червня 2013 р.) визначила стратегічні завдання розвитку вищої освіти, серед яких: подальше вдосконалення процедур і технологій зовнішнього незалежного оцінювання якості освіти як передумови забезпечення рівного доступу до навчання у вищій освіті; централізація управління вищою освітою, реформування та оптимізація мережі ЗВО, приведення іії у відповідність до потреб розвитку національної економіки та запитів ринку праці; створення дослідницьких університетів; розширення автономії 3ВО [34]. Системне, повне і послідовне виконання запропонованих першочергових заходів у національній системі освіти (здійснення комплексу наступних невідкладних дій загальносистемного значення) зможе надати нового імпульсу іï розвитку, підвищить якість, конкурентоспроможність, динамізм модернізації, а відтак прискорить входження України до когорти провідних країн світу.

В умовах посилення глобалізаційних процесів, коли головним пріоритетом та стратегічним курсом виступає економіка інноваційного розвитку, побудована на економіці знань, склалися несприятливі умови для формування, ефективного використання та розвитку людського капіталу, який $є$ ключовим ресурсом підвищення конкурентоспроможності національної економіки. Для України пошук нової моделі функціонування системи державного регулювання розвитку людського капіталу $\epsilon$ актуальною та об'єктивною потребою, яка дозволить зміцнити конкурентні переваги країни в умовах глобальних викликів та загроз [35].

В сучасних умовах пандемії на COVID-19 (різноманітні штами «Дельта», «Омікрон») проблема якості вищої освіти $\epsilon$ не просто актуальною, а вкрай важливою для поступу України в європейський та світовий простір вищої освіти, правового, економічного, промислового, гуманітарного, медичного та фармацевтичного розвитку нації, взагалі, та окремої людини, зокрема. Як засвідчують Скиба М., Крікунов М. та інш., система вищої освіти в Україні може бути охарактеризована як масова вища освіта без явно виділених лідерів якості за категоріями досліджень, зі слабкою інтернаціоналізацією та майже цілковитим браком дієвого зв'язку з ринком праці та високотехнологічним бізнесом [36]. Вища освіта, як глобальна галузь постійно набирає обертів. У світі налічувалося 26368 3ВО, із яких 18500 були університети, проте динаміка постійно зростає. Так, за період з 2000 р. по 2014 р. чисельність студентів у світі стала майже у 2 рази більше. Саме основний тягар потоку студентів покладається на приватні 3ВО, в гіршому стані знаходяться саме державні університети.

Найбільш повна й актуальна інформація щодо кількості 3ВО та їхніх філій доступна у реєстрі суб'єктів освітньої діяльності Єдиної державної електронної 
бази 3 питань освіти (СДЕБО) [37]. Так, за даними ЄДЕБО станом на листопад 2019 р. в Україні нараховувалося 671 ЗВО. Цю величезну за мірками країн СС цифру складають: 193 університети, 152 інститути, 127 відокремлених підрозділів, 118 інших наукових установ (організацій), 73 академії та 8 наукових центрів. Серед усіх національних університетів (118 3ВО) виокремлюємо такі групи: 24 класичні, 17 технічних, 11 таких, що підпорядковуються силовим відомствам, по 10 аграрних і мистецьких, 9 медичних, 8 транспортних, по 6 економічних і педагогічних, 3 архітектурні, ще 14 університетів згруповано в «Інші». Концентрація здобувачів вищої освіти за регіонами свідчить про те що, найбільша кількість студентів навчається в м. Києві (343 тис. осіб), м. Харкові (154 тис. 800 осіб), м. Львові (108 тис. осіб), м. Дніпро (92 тис. осіб). Показовим для характеристики якості вищої освіти також $є$ те, що в університетах України загалом зараховано більше здобувачів вищої освіти за контрактною формою навчання, аніж за бюджетним фінансуванням: із 1,3 млн здобувачів вищої освіти 739 тис. навчається на контрактній основі (56\%) і 582 тис. (44\%) за рахунок, в основному, державного бюджету. Серед 1,3 млн студентів університетів, академій та інститутів майже 400 тис. (31\%) навчаються на заочній формі, $2200(0,2 \%)-$ на вечірній. Відповідно до наявних у відкритому доступі даних станом на листопад 2019 р., у 2018 р. університети, академії, інститути Україні випустили майже 171 тис. студентів. За спеціальностями випускники ЗВО України розподілилися таким чином. Констатуємо колосальну кількісну перевагу студентів соціально-економічного і гуманітарного напряму - 75 тис. осіб. Далі у порядку спадання - 28 тис. майбутніх інженерів, 14 тис. медиків, 12 тис. педагогів, 10 тис. транспортників, 6,2 тис. представників природничих наук, 4,8 тис. архітекторів і будівельників, 4,8 тис. працівників 3 вищою освітою у сфері послуг, майже 16 тис. - представники інших спеціальностей.

При оцінюванні успішності студентів 3 дисциплін необхідно використовувати єдину шкалу, яка б встановлювала взаємозв'язок між рейтинговим показником з дисципліни, національною шкалою оцінювання знань i шкалою оцінок ECTS [38]. У Львівському національному медичному університеті імені Данила Галицького рейтингова система оцінювання, як i кредитно-модульна система організації навчального процесу використовується, починаючи з 2005-2006 навчального року, відповідно до запропонованого МО3 України Навчального плану підготовки фахівців освітньо-кваліфікаційного рівня «спеціаліст» кваліфікації «лікар» та Тимчасової інструкції 3 оцінювання навчальної діяльності студентів при кредитно-модульній системі організації навчального процесу. Для оцінювання використовується 200-бальна шкала, яка інтегрально характеризує успішність і знання студентів та дає можливість детально розділити їх на групи, встановлені шкалою ECTS.

У сучасних умовах увага науковців має бути сконцентрована, насамперед, на дослідженні теоретичних і методологічних засад підготовки адекватних управлінських рішень, забезпеченні достатньої комплексності досліджень системних аспектів державного регулювання i саморегулювання у фармацевтичній галузі України та моделей ії розвитку [39]. Це чудова нагода для 
обміну досвідом i думками 3 нагальних питань сучасності: проблем фармацевтичної освіти й науки, управління та правового регулювання у фармації, особливостей фармацевтичної допомоги при окремих нозологіях та багатьох інших. Це справді унікальна можливість для критичного аналізу нинішньої ситуації, обміну досвідом і пошуку оптимального шляху розвитку української фармації.

У Верховній Раді України 18 січня 2022р. зареєстровано проект закону №6495-1 «Про внесення змін до деяких Законів України щодо підготовки в інтернатурі та безперервного професійного розвитку медичних та фармацевтичних працівників» (далі — проект закону). Ініціатором подання $\epsilon$ група народних депутатів на чолі з Оксаною Дмитрієвою, народним депутатом від партії «Слуга народу». Варто зауважити, що даний проект закону $\epsilon$ альтернативним до зареєстрованого раніше проекту №6495 від 31.12.2021 p. Автором законодавчої ініціативи була Інна Совсун, народний депутат від партії «Голос». У супровідній документації зазначається, що трансформаційні процеси, які наразі відбуваються у сфері охорони здоров'я, потребують нових підходів до впровадження післядипломної освіти професійних медичних та фармацевтичних кадрів [40]. Проектом закону пропонується внести зміни у ряд профільних нормативно-правових актів, а саме: у Законі України «Про освіту», у ст. 18, пропонується виключити положення, які описують проходження інтернатури та лікарської резидентури; ст. 60 Закону України «Про вищу освіту» доповнюватиметься новими пунктами. Зокрема, змінами зазначається, що інтернатура передбачатиме первинну спеціалізацію магістрів медичного або фармацевтичного спрямування в закладах вищої (післядипломної) освіти у співпраці $з$ базами стажування лікарів (провізорів)-інтернів відповідно до програми підготовки в інтернатурі за лікарськими та провізорськими спеціальностями для отримання кваліфікації лікаря-спеціаліста або провізораспеціаліста. Програма підготовки в інтернатурі скрадатиметься iз 2 складових: освітньої та практичної. Освітня складова інтернатури проводитиметься в закладах вищої (післядипломної) освіти, що мають ліцензію на провадження освітньої діяльності за відповідними освітніми програмами та становить не менше 40\% загального обсягу підготовки в інтернатурі. Практична складова у закладах охорони здоров'я, які будуть визначені центральним органом виконавчої влади у сфері охорони здоров'я як бази стажування лікарів (провізорів)-інтернів. Змінами надається визначення поняття «база стажування лікарів (провізорів)-інтернів»: заклади охорони здоров'я незалежно від форми власності, що відповідають вимогам, визначеним центральним органом виконавчої влади у сфері охорони здоров' я до зазначених баз стажування, мають профільні відділення відповідно до спеціальностей інтернатури, на території яких функціонують відповідні профільні кафедри згідно 3 договорами про спільну діяльність із закладами вищої (післядипломної) освіти. Університетські клініки відповідно до свого статусу також визначено базами стажування лікарів (провізорів)-інтернів. Окрім того, змінами зазначається, що підготовка в інтернатурі буде здійснюватися як за кошти державного бюджету, так і за 
кошти фізичних або юридичних осіб. Що стосується іноземців та осіб без громадянства, що не мають посвідки на постійне проживання на території України, вони мають право на підготовку в інтернатурі за кошти фізичних або юридичних осіб за умови наявності сертифіката про рівень володіння державною мовою, здобутого відповідно до Закону України «Про забезпечення функціонування української мови як державної». Після закінчення підготовки в інтернатурі лікарі (провізори)-інтерни проходитимуть підсумкову атестацію для оцінювання відповідності здобутих ними результатів навчання кваліфікаційним вимогам 3 присвоєнням звання «лікар-спеціаліст» або «провізор-спеціаліст» 3 відповідної спеціальності. Лікарська резидентура проводитиметься в закладах вищої (післядипломної) освіти у співпраці з базами стажування лікарів-резидентів відповідно до програми підготовки в резидентурі та $\epsilon$ формою спеціалізації лікарів-спеціалістів за певними лікарськими спеціальностями для отримання кваліфікації лікаря-спеціаліста згідно 3 переліком лікарських спеціальностей, затвердженим центральним органом виконавчої влади у сфері охорони здоров'я $[41,42]$. Окрім змін у поняттєвий апарат закону, пропонується назву ст. 75 викласти в новій редакції, а саме «Підготовка, перепідготовка, підвищення кваліфікації та безперервний професійний розвиток медичних, фармацевтичних працівників та фахівців 3 реабілітації» та доповнити новим пунктом, в якому закріплюватиметься норма відносно того, що медичні та фармацевтичні працівники мають проходити заходи безперервного професійного розвитку. Безперервний розвиток медичних та фармацевтичних працівників здійснюватиметься закладами фахової передвищої та вищої (післядипломної) освіти, науковими установами, багатопрофільними закладами охорони здоров'я, іншими провайдерами, акредитованими центральним органом виконавчої влади у сфері охорони здоров'я [42].

Зазначимо, що основним нормативно-правовим документом прийнято Постанову Кабінету Міністрів України від 30 грудня 2015 р. №1187 «Про затвердження Ліцензійних умов провадження освітньої діяльності» (із змінами, внесеними згідно з Постановами КМ №347 від 10.05.2018, №180 від 03.03.2020, №365 від 24.03.2021) (далі Постанова) у якій затверджено Ліцензійні умови провадження освітньої діяльності [43].

У загальних положеннях Постанови вказано, що ліцензуванню у сфері післядипломної освіти підлягають такі види освітньої діяльності - підвищення кваліфікації або підготовка в інтернатурі за відповідною спеціальністю.

Ліцензуванню підлягає освітня діяльність 3 підвищення кваліфікації працівників, обов'язковість якої передбачена законом, 3 підготовки в інтернатурі.

До здобувачів ліцензій (ліцензіатів) у сфері післядипломної освіти на провадження освітньої діяльності належать:

заклади післядипломної, вищої та фахової освіти;

наукові установи; 
$>\quad$ заклади післядипломної, вищої та фахової освіти (для територіально відокремлених структурних підрозділів закладів освіти).

У разі запровадження дистанційної форми навчання ліцензіат повинен додатково дотримуватися вимог до кадрового i навчально-методичного забезпечення дистанційної форми навчання, а також забезпечити створення i функціонування системи управління дистанційною формою навчання та вебресурсами освітніх компонентів (навчальних дисциплін (освітніх програм).

Організаційні вимоги щодо започаткування та провадження освітньої діяльності свідчать про те, що ліцензіат забезпечує провадження освітньої діяльності виключно в місцях іiі провадження, зазначених у документах, поданих органу ліцензування, крім провадження освітньої діяльності за місцем проживання дитини на рівні дошкільної освіти та у сфері позашкільної освіти, провадження освітньої діяльності за місцем, наданим замовником для отримання короткострокових освітніх послуг у сфері позашкільної освіти (семінару, лекції, тренінгу, вебінару тощо), крім провадження освітньої діяльності з підвищення кваліфікації працівника за місцем його роботи у сфері післядипломної освіти.

У розділі «Спеціальні вимоги щодо започаткування та провадження освітньої діяльності» у підрозділі «Започаткування та провадження освітньої діяльності на рівні вищої освіти» відокремлено кадрові вимоги щодо започаткування та провадження освітньої діяльності за рівнем вищої освіти та освітніми програмами, що передбачають присвоєння професійної кваліфікації 3 професій, для яких запроваджено додаткове регулювання, згідно яких здобувач ліцензії (ліцензіат) повинен бути забезпечений науково-педагогічними (педагогічними) та/або науковими працівниками, необхідними для реалізації освітніх компонентів, передбачених освітньою (освітніми) програмою (програмами) на відповідному рівні вищої освіти.

Частка науково-педагогічних (педагогічних) та/або наукових працівників, які мають науковий ступінь та/або вчене звання та працюють у здобувача ліцензії (ліцензіата) за основним місцем роботи, повинна становити не менше 50 відсотків на відповідному рівні вищої освіти або за освітньою програмою, що передбачає присвоєння професійної кваліфікації 3 професій, для яких запроваджено додаткове регулювання, на відповідному рівні вищої освіти, 3 них осіб, які мають науковий ступінь доктора наук та/або вчене звання професора, повинна становити:

$\bullet$
відсотків;

- $\quad$ для третього (освітньо-наукового/освітньо-творчого) рівня вищої освіти - не менше двох докторів наук (для освітньо-творчих програм замість доктора наук може враховуватися доктор мистецтва) для здійснення керівництва науковою складовою кожної освітньо-наукової/освітньо-творчої програми.

Склад науково-педагогічних, педагогічних та наукових працівників, які мають освітню та професійну кваліфікацію, відповідну освітній програмі, повинен бути не менш як три особи, які мають науковий ступінь та/або вчене звання та працюють у закладі освіти за основним місцем роботи. 
Здобувач ліцензії (ліцензіат) повинен забезпечити кожний освітній компонент освітньої програми на відповідному рівні вищої освіти науковопедагогічними (педагогічними) та/або науковими працівниками з урахуванням відповідності їх освітньої та/або професійної кваліфікації. Науково-педагогічні, педагогічні та наукові працівники, які забезпечують освітній процес, повинні мати не менше чотирьох досягнень у професійній діяльності за останні п'ять років.

Відповідність освітньої та професійної кваліфікації науково-педагогічних, педагогічних та наукових працівників освітньому компоненту визначається на підставі наявності щонайменше п'яти публікацій у наукових виданнях, які включені до переліку фахових видань України, до наукометричних баз, зокрема Scopus, Web of Science Core Collection, протягом останніх п'яти років, а також документів встановленого зразка про:

* про вищу освіту;

* присудження наукового ступеня (однакова за змістом спеціальність (предметна спеціальність, спеціалізація);

* наявність досвіду професійної діяльності (заняття) за відповідним фахом (спеціальністю, спеціалізацією) не менше п'яти років (крім педагогічної, науково-педагогічної, наукової діяльності);

керівництво (консультування) дисертації на здобуття наукового ступеня за спеціальністю, що була захищена в Україні або за кордоном.

Досягнення у професійній діяльності, які зараховуються за останні п’ять років:

1) наявність не менше п'яти публікацій у періодичних наукових виданнях, що включені до переліку фахових видань України, до наукометричних баз, зокрема Scopus, Web of Science Core Collection

Коментар від авторів: слід вказати, що необхідно також враховувати наявність не менше п'яти наукових публікацій у наукових виданнях, включених до переліку наукових фахових видань України або щонайменше однісї статті у періодичних наукових виданнях інших держав, які входять до Організації Економічного Співробітництва та розвитку Свропейського Союзу 3 наукового напряму, за яким викладається освітня дисципліна, та індексованих в міжнародних наукометричних базах.

2) наявність одного патенту на винахід або п'яти деклараційних патентів на винахід чи корисну модель, включаючи секретні, або наявність не менше п’яти свідоцтв про реєстрацію авторського права на твір 
3) наявність виданого підручника чи навчального посібника (включаючи електронні) або монографії (загальним обсягом не менше 5 авторських аркушів), в тому числі видані у співавторстві (обсягом не менше 1,5 авторського аркуша на кожного співавтора)

4) наявність виданих навчально-методичних посібників/посібників для самостійної роботи здобувачів вищої освіти та дистанційного навчання, електронних курсів на освітніх платформах ліцензіатів, конспектів лекцій/практикумів/методичних вказівок/рекомендацій/ робочих програм, інших друкованих навчально-методичних праць загальною кількістю три найменування

5) захист дисертації на здобуття наукового ступеня

Коментар від авторів: оскільки враховуються досягнення у професійній діяльності за останні п'ять років, а науковий ступінь не має терміну дії, необхідно уточнити цей пункт, наприклад, позначкою «безстроково».

6) наукове керівництво (консультування) здобувача, який одержав документ про присудження наукового ступеня

7) участь в атестації наукових кадрів як офіційного опонента або члена постійної спеціалізованої вченої ради, або члена не менше трьох разових спеціалізованих вчених рад

8) виконання функцій (повноважень, обов'язків) наукового керівника або відповідального виконавця наукової теми (проекту), або головного редактора/члена редакційної колегії/експерта (рецензента) наукового видання, включеного до переліку фахових видань України, або іноземного наукового видання, що індексується в бібліографічних базах 
9) робота у складі експертної ради 3 питань проведення експертизи дисертацій МОН або у складі галузевої експертної ради як експерта Національного агентства із забезпечення якості вищої освіти, або у складі Акредитаційної комісії, або міжгалузевої експертної ради з вищої освіти Акредитаційної комісії, або трьох експертних комісій $\mathrm{MOH} /$ зазначеного Агентства, або Науково-методичної ради/науково-методичних комісій (підкомісій) з вищої або фахової передвищої освіти МОН, наукових/науковометодичних/експертних рад органів державної влади та органів місцевого самоврядування, або у складі комісій Державної служби якості освіти із здійснення планових (позапланових) заходів державного нагляду (контролю)

10) участь у міжнародних наукових та/або освітніх проектах, залучення до міжнародної експертизи, наявність звання “суддя міжнародної категорії”

11) наукове консультування підприємств, установ, організацій не менше трьох років, що здійснювалося на підставі договору із закладом вищої освіти (науковою установою)

12) наявність апробаційних та/або науково-популярних, та/або консультаційних (дорадчих), та/або науково-експертних публікацій 3 наукової або професійної тематики загальною кількістю не менше п'яти публікацій

13) проведення навчальних занять із спеціальних дисциплін іноземною мовою (крім дисциплін мовної підготовки) в обсязі не менше 50 аудиторних годин на навчальний рік 
14) керівництво студентом, який зайняв призове місце на I або II етапі Всеукраїнської студентської олімпіади (Всеукраїнського конкурсу студентських наукових робіт), або робота у складі організаційного комітету / журі Всеукраїнської студентської олімпіади (Всеукраїнського конкурсу студентських наукових робіт), або керівництво постійно діючим студентським науковим гуртком / проблемною групою; керівництво студентом, який став призером або лауреатом Міжнародних, Всеукраїнських мистецьких конкурсів, фестивалів та проектів, робота у складі організаційного комітету або у складі журі міжнародних, всеукраїнських мистецьких конкурсів, інших культурно-мистецьких проектів (для забезпечення провадження освітньої діяльності на третьому (освітньотворчому) рівні); керівництво здобувачем, який став призером або лауреатом міжнародних мистецьких конкурсів, фестивалів, віднесених до Європейської або Всесвітньої (Світової) асоціації мистецьких конкурсів, фестивалів, робота у складі організаційного комітету або у складі журі зазначених мистецьких конкурсів, фестивалів); керівництво студентом, який брав участь в Олімпійських, Паралімпійських іграх, Всесвітній та Всеукраїнській Універсіаді, чемпіонаті світу, Свропи, Свропейських іграх, етапах Кубка світу та Європи, чемпіонаті України; виконання обов'язків тренера, помічника тренера національної збірної команди України з видів спорту; виконання обов'язків головного секретаря, головного судді, судді міжнародних та всеукраїнських змагань; керівництво спортивною делегацією; робота у складі організаційного комітету, суддівського корпусу

15) керівництво школярем, який зайняв призове місце III-IV етапу Всеукраїнських учнівських олімпіад з базових навчальних предметів, II-III етапу Всеукраїнських конкурсів-захистів науково-дослідницьких робіт учнів - членів Національного центру “Мала академія наук України"; участь у журі III-IV етапу Всеукраїнських учнівських олімпіад 3 базових навчальних предметів чи II-III етапу Всеукраїнських конкурсів-захистів науково-дослідницьких робіт учнів - членів Національного центру “Мала академія наук України" (крім третього (освітньо-наукового/освітньотворчого) рівня)

16) наявність статусу учасника бойових дій (для вищих військових навчальних закладів, закладів вищої освіти із специфічними умовами навчання, військових навчальних підрозділів закладів вищої освіти) 
17) участь у міжнародних операціях з підтримання миру і безпеки під егідою Організації Об’єднаних Націй (для вищих військових навчальних закладів, закладів вищої освіти із специфічними умовами навчання, військових навчальних підрозділів закладів вищої освіти)

18) участь у міжнародних військових навчаннях (тренуваннях) за участю збройних сил країн - членів НАТО (для вищих військових навчальних закладів, військових навчальних підрозділів закладів вищої освіти)

19) діяльність за спеціальністю у формі участі у професійних та/або громадських об’єднаннях

20) досвід практичної роботи за спеціальністю не менше п’яти років (крім педагогічної, науково-педагогічної, наукової діяльності)

Коментар від авторів: досвід практичної роботи за спеціальністю викладача практично неможливо встановити, якщо особа працювала у приватній компанії 3 назвою, $з$ якої не можливо зробити висновок про напрямок діяльності та профіль спеціальності.

Слід вказати, що частина з вимог, які зазначено вище, взагалі не має відношення до спеціальності, яку викладає кафедра. Частина інших вимог може бути використана лише для окремих спеціальностей.

Під час визначення досягнень у професійній діяльності науковопедагогічного (наукового) працівника можуть зараховуватися досягнення за попередніми місцями роботи, п’ятирічний строк може продовжуватися на час перерви в роботі 3 об'єктивних причин (соціальна відпустка, академічна відпустка, призов/мобілізація на військову службу чи військова служба за контрактом, тривала непрацездатність тощо).

Вимога наявності досягнень у професійній діяльності не застосовусться до науково-педагогічних (наукових) працівників із стажем науково-педагогічної роботи менше трьох років, працівників, що мають статус учасника бойових дій, а також до фахівців-практиків, які працюють на посадах науково-педагогічних (наукових) працівників на умовах сумісництва в обсязі 0,25 або менше, або 150 годин навчального навантаження на навчальний рік.

Для 3ВО, в яких здійснюється підготовка фахівців за мистецькими спеціальностями галузі знань “02 Культура і мистецтво”, спеціальностями “014 Середня освіта (Музичне мистецтво)", “014 Середня освіта (Образотворче мистецтво)", замість наукових публікацій у наукових виданнях, включених до переліку наукових фахових видань України, науково-педагогічним (педагогічним) працівникам мистецьких спеціальностей можуть зараховуватися 
такі оприлюднені здобутки: літературні твори, переклади літературних творів, твори живопису, декоративного мистецтва, архітектури, архітектурні проекти, скульптурні, графічні, фотографічні твори, твори дизайну, музичні твори, аудіота відеотвори, передачі (програми) організації мовлення, медіатори, сценічні постановки, концертні програми (сольні та ансамблеві) кінотвори, анімаційні твори, аранжування творів, рекламні твори.

До матеріально-технічного забезпечення освітньої діяльності у сфері післядипломної освіти до здобувача ліцензії (ліцензіата) встановлюються такі технологічні вимоги:

1) наявність документів, які підтверджують право власності чи користування майном для провадження освітньої діяльності;

2) забезпечення навчальними приміщеннями та засобами провадження освітньої діяльності в обсязі, достатньому для виконання затверджених освітньої (освітніх) програми (програм) підвищення кваліфікації, програм підготовки в інтернатурі та навчальних планів відповідної спеціальності.

Для 3ВО, який провадить освітню діяльність тільки у сфері післядипломної освіти, площа навчальних приміщень для здійснення освітнього процесу повинна становити не менш як 2,4 кв. метра на одну особу з урахуванням не більше трьох змін навчання та ліцензованих обсягів всіх чинних ліцензій (крім підвищення кваліфікації у дистанційній формі навчання за державним замовленням та підвищення кваліфікації працівника за місцем його роботи).

Навчально-методичне забезпечення освітньої діяльності у сфері післядипломної освіти до здобувача ліцензії (ліцензіата) передбачає наявність затверджених освітньої (освітніх) програми (програм) підвищення кваліфікації, програм підготовки в інтернатурі та навчальних планів відповідної спеціальності (освітньої програми), програм навчальних дисциплін.

До інформаційного забезпечення освітньої діяльності у сфері післядипломної освіти до здобувача ліцензії (ліцензіата) встановлюється вимога щодо забезпечення доступу здобувачів освіти до електронних версій необхідних підручників, навчальних посібників, конспектів лекцій тощо (або відповідного електронного ресурсу).

Інші розділи Постанови наведено у табл. 1.

Таблиия 1

\section{Розділи Постанови}

№ 3/II Назва розділу Постанови

1. Перелік документів, який подає здобувач ліцензії (ліцензіат) для започаткування (розширення) провадження освітньої діяльності у сфері післядипломної освіти

2. Започаткування та провадження освітньої діяльності на рівні фахової передвищої освіти

3. Кадрові вимоги щодо започаткування та провадження освітньої діяльності на рівні фахової передвищої освіти 
$4 . \quad$ Технологічні вимоги щодо забезпечення започаткування та провадження освітньої діяльності за рівнем фахової передвищої освіти

5. Перелік документів, які подає здобувач ліцензії (ліцензіат) для започаткування (розширення) провадження освітньої діяльності на рівні фахової передвищої освіти

6. Започаткування та провадження освітньої діяльності на рівні професійної (професійно-технічної) освіти

7. Кадрові вимоги щодо започаткування та провадження освітньої діяльності за рівнем професійної (професійно-технічної) освіти

8. Технологічні вимоги щодо започаткування та провадження освітньої діяльності за рівнем професійної (професійно-технічної) освіти

9. Перелік документів, які подає здобувач ліцензії (ліцензіат) для започаткування (розширення) провадження освітньої діяльності за рівнем професійної (професійно-технічної) освіти

10. Започаткування та провадження освітньої діяльності на рівні повної загальної середньої освіти

11. Кадрові вимоги щодо започаткування та провадження освітньої діяльності за рівнями повної загальної середньої освіти (початкової, базової середньої, профільної середньої освіти)

12. Технологічні вимоги щодо провадження освітньої діяльності за рівнями повної загальної середньої освіти (початкової, базової середньої, профільної середньої освіти)

13. Перелік документів, які подає здобувач ліцензії (ліцензіат) для започаткування (розширення) провадження освітньої діяльності

на відповідному рівні повної загальної середньої освіти

14. Започаткування та провадження освітньої діяльності за рівнем дошкільної освіти

15. Кадрові вимоги щодо започаткування та провадження освітньої діяльності за рівнем дошкільної освіти

16. Технологічні вимоги щодо започаткування та провадження освітньої діяльності на рівні дошкільної освіти

17. Перелік документів, які подає здобувач ліцензії (ліцензіат) для започаткування (розширення) провадження освітньої діяльності на рівні дошкільної освіти

18. Започаткування та провадження освітньої діяльності у сфері позашкільної освіти

19. Кадрові вимоги щодо започаткування та провадження освітньої діяльності у сфері позашкільної освіти

20. Технологічні вимоги щодо започаткування та провадження освітньої діяльності у сфері позашкільної освіти 
21. Перелік документів, які подає здобувач ліцензії (ліцензіат) для започаткування (розширення) провадження освітньої діяльності у сфері позашкільної освіти

Постанова містить 55 додатків, що наведено у табл. 2.

Таблиия 2

\section{Зміст додатків до Постанови}

\section{№} उмicт

\section{додатку}

1. ЗАЯВА про звуження провадження освітньої діяльності на рівні вищої освіти

2. ЗАЯВА про звуження провадження освітньої діяльності на рівні вищої освіти

3. ЗАЯВА про звуження провадження освітньої діяльності у певному місці провадження освітньої діяльності

4. ЗАЯВА про звуження провадження освітньої діяльності у сфері післядипломної освіти

5. ЗАЯВА про звуження провадження освітньої діяльності на рівні фахової передвищої освіти

6. ЗАЯВА про звуження провадження освітньої діяльності 3 підготовки іноземців та осіб без громадянства за акредитованими спеціальностями

7. ЗАЯВА про звуження провадження освітньої діяльності на рівні професійної (професійно-технічної) освіти

8. ЗАЯВА про звуження провадження освітньої діяльності на рівні професійної (професійно-технічної) освіти у відокремленому структурному підрозділі

9. ЗАЯВА про звуження провадження освітньої діяльності за певною професією або класом класифікаційного угруповання професій, видом підготовки, 3 підготовки іноземців та осіб без громадянства за професією відповідного виду підготовки

10. ЗАЯВА про переоформлення ліцензій на рівні вищої освіти

11. ЗАЯВА про переоформлення ліцензій на рівні фахової передвищої освіти

12. ЗАЯВА про переоформлення ліцензії на рівні професійної (професійно-технічної) освіти

13. ЗАЯВА про внесення змін до ліцензії на провадження освітньої діяльності у зв'язку із зміною місця провадження

14. ЗАЯВА про отримання ліцензії на провадження освітньої діяльності (розширення провадження освітньої діяльності) на рівні вищої освіти

15. ВІДОМОСТІ про науково-педагогічних, педагогічних та наукових працівників, що підтверджують їх освітню та/або професійну 
кваліфікацію для забезпечення освітнього процесу на відповідному рівні вищої освіти або за освітньою програмою, що передбачає присвоєння професійної кваліфікації 3 професій, для яких запроваджено додаткове регулювання, на відповідному рівні вищої освіти

16. ВІДОМОСТІ про наявність науково-педагогічних, педагогічних та наукових працівників, які працюють за основним місцем роботи, мають відповідну освітній програмі освітню та/або професійну кваліфікацію (крім розширення провадження освітньої діяльності щодо збільшення ліцензованого обсягу на певному рівні вищої освіти)

17. ВІДОМОСТІ про матеріально-технічне забезпечення освітньої діяльності (для освітніх програм, що передбачають присвоєння професійної кваліфікації 3 професій, для яких запроваджено додаткове регулювання)

18. ВІДОМОСТІ про засоби провадження освітньої діяльності (для освітніх програм, що передбачають присвоєння професійної кваліфікації 3 професій, для яких запроваджено додаткове регулювання, на відповідному рівні вищої освіти)

19. ІНФОРМАЦІЯ про наявність у відкритому доступі на власному веб-сайті інформації та документів, передбачених Законами України "Про освіту" та "Про вищу освіту"

20. ОПИС документів, що подаються для отримання ліцензії на започаткування провадження освітньої діяльності або розширення провадження освітньої діяльності на відповідному рівні вищої освіти або за освітньою програмою, що передбачає присвоєння професійної кваліфікації 3 професій, для яких запроваджено додаткове регулювання, на відповідному рівні вищої освіти/отримання ліцензії на започаткування провадження освітньої діяльності або розширення провадження освітньої діяльності на відповідному рівні вищої освіти або за освітньою програмою, що передбачає присвоєння професійної кваліфікації 3 професій, для яких запроваджено додаткове регулювання, на відповідному рівні вищої освіти, закладом освіти іноземної держави, відокремлений структурний підрозділ (філія) якого створюється і функціонує на території України

21. ЗАЯВА про отримання ліцензії на провадження освітньої діяльності (розширення провадження освітньої діяльності) у сфері післядипломної освіти

22. ВІДОМОСТІ про педагогічних, науково-педагогічних, наукових та інших працівників, що підтверджують їх освітню та/або професійну кваліфікацію для забезпечення освітнього процесу за освітньою (освітніми) програмами кваліфікації із спеціальності підвищення або програмами 
23. ВІДОМОСТІ про матеріально-технічне забезпечення освітньої діяльності у сфері післядипломної освіти

24. ВІДОМОСТІ про засоби провадження освітньої діяльності у сфері післядипломної освіти

25. ІНФОРМАЦІЯ про наявність у відкритому доступі на власному веб-сайті інформації та документів, передбачених Законом України "Про освіту"

26. ОПИС документів, що подаються для отримання ліцензії на провадження освітньої діяльності або розширення провадження освітньої діяльності у сфері післядипломної освіти

27. ЗАЯВА про отримання ліцензії на провадження освітньої діяльності (розширення провадження освітньої діяльності) на рівні фахової передвищої освіти

28. ВІДОМОСТІ про педагогічних працівників, які забезпечують освітній процес

$3 a$

спеціальністю

(код та найменування спеціальності) на рівні фахової передвищої освіти

29. ВІДОМОСТІ про педагогічних працівників, які працюють у здобувача ліцензії (ліцензіата) за основним місцем роботи, мають освітню та/або професійну кваліфікацію, яка відповідає спеціальності (код та найменування спеціальності, що ліцензується) на рівні ф ахової передвищої освіти

30. ВІДОМОСТІ про матеріально-технічне забезпечення освітньої діяльності закладу освіти на рівні фахової передвищої освіти

31. ВІДОМОСТІ про навчально-методичне забезпечення освітньої діяльності за спеціальністю на рівні фахової передвищої освіти

32. ВІДОМОСТІ

про інформаційне забезпечення освітньої діяльності за спеціальністю на рівні фахової передвищої освіти

33. І ІНФОРМАЦІЯ про наявність у відкритому доступі на власному веб-сайті інформації та документів, передбачених Законами України "Про освіту" та "Про фахову передвищу освіту"

34. ОПИС документів, що подаються для отримання ліцензії на започаткування провадження освітньої діяльності або розширення провадження освітньої діяльності за спеціальністю на рівні фахової передвищої світи/ отримання ліцензії на провадження освітньої діяльності або розширення провадження освітньої діяльності за спеціальністю на рівні фахової передвищої освіти закладом освіти 
іноземної держави, відокремлений структурний підрозділ (філія) якого створюється і функціонує на території України

35. ЗАЯВА про отримання ліцензії на провадження освітньої діяльності (розширення провадження освітньої діяльності) на рівні професійної (професійно-технічної) освіти

36. ВІДОМОСТІ про кількісні та якісні показники кадрового забезпечення освітньої діяльності на рівні професійної (професійно-технічної) освіти

37. ВІДОМОСТІ про кількісні та якісні показники матеріальнотехнічного забезпечення освітньої діяльності на рівні професійної (професійно-технічної) освіти

38. ВІДОМОСТІ про навчально-методичне забезпечення освітньої діяльності на рівні професійної (професійно-технічної) освіти

39. ВІДОМОСТІ про інформаційне забезпечення освітньої діяльності на професійної (професійно-технічної) освіти

40. ІНФОРМАЦІЯ про наявність у відкритому доступі на власному веб-сайті інформації та документів, передбачених Законом України "Про освіту"

41. ОПИС документів, що подаються для отримання ліцензії на започаткування провадження освітньої діяльності на рівні професійної (професійно-технічної) освіти або розширення провадження освітньої діяльності на рівні професійної (професійно-технічної) освіти

42. ОПИС документів, що подаються для отримання ліцензії на провадження освітньої діяльності на рівні професійної (професійно-технічної) освіти або розширення провадження освітньої діяльності на рівні професійної (професійно-технічної) освіти закладом освіти іноземної держави, відокремлений структурний підрозділ (філія) якого створюється і функціонує на території України

43. ЗАЯВА про отримання ліцензії на провадження освітньої діяльності (розширення провадження освітньої діяльності) на рівні повної загальної середньої освіти

44. ВІДОМОСТІ про кількісні та якісні показники кадрового забезпечення освітньої діяльності на певному рівні повної загальної середньої освіти, необхідного для виконання вимог державного стандарту відповідного рівня повної загальної середньої освіти (у разі розширення провадження освітньої діяльності)

45. ВІДОМОСТІ про матеріально-технічне забезпечення освітньої діяльності на певному рівні повної загальної середньої освіти, необхідне для виконання вимог державного стандарту відповідного рівня повної загальної середньої освіти (у разі розширення провадження освітньої діяльності) 
46. ВІДОМОСТІ про навчально-методичне забезпечення освітньої діяльності на певному рівні повної загальної середньої освіти, необхідне для виконання державного стандарту освіти відповідного рівня повної загальної середньої освіти (у разі розширення провадження освітньої діяльності)

47. ІНФОРМАЦІЯ про наявність у відкритому доступі на власному веб-сайті (у разі їх відсутності - на веб-сайтах своїх засновників) інформації та документів, передбачених Законами України “Про освіту" та "Про повну загальну середню освіту" (у разі розширення провадження освітньої діяльності)

48. ОПИС документів, що подаються здобувачем ліцензії для отримання ліцензії на започаткування провадження освітньої діяльності на певному рівні повної загальної середньої освіти

49. ОПИС документів, що подаються ліцензіатом для розширення провадження освітньої діяльності на певному рівні повної загальної середньої освіти

50. ЗАЯВА про отримання ліцензії на провадження освітньої діяльності (розширення провадження освітньої діяльності) на рівні дошкільної освіти

51. ОПИС документів, що подаються юридичною особою (закладом дошкільної освіти) / юридичною особою, що має дошкільний підрозділ / фізичною особою - підприємцем для отримання ліцензії на провадження освітньої діяльності на рівні дошкільної освіти

52. ОПИС документів, що подаються фізичною особою - підприємцем, яка провадитиме освітню діяльність на рівні дошкільної освіти самостійно (без використання найманої праці) для отримання ліцензії на провадження освітньої діяльності на рівні дошкільної освіти

53. ЗАЯВА про отримання ліцензії на провадження освітньої діяльності (розширення провадження освітньої діяльності) у сфері позашкільної освіти

54. ОПИС документів, що подаються здобувачем ліцензії (ліцензіатом) для отримання ліцензії на провадження освітньої діяльності (розширення провадження освітньої діяльності) у сфері позашкільної освіти

55. ОПИС документів, що подаються фізичною особою - підприємцем, яка провадить (провадитиме) освітню діяльність у сфері позашкільної освіти самостійно (без використання найманої праці), для отримання ліцензії на провадження освітньої діяльності у сфері позашкільної освіти

Наприкінці Постанови приведено перелік постанов Кабінету Міністрів України, що втратили чинність.

До Закону про ліцензування видів господарської діяльності внесено 
уточнення, що освітня діяльність ліцензується з урахуванням особливостей, визначених спеціальними законами у сфері освіти (ст. 7.1.6). Утім, це не усуває всіх проблем, оскільки «врахування особливостей» може стосуватися певних деталей, але не принципів ліцензування [44-47].

Закон про освіту [48] також встановив загальну для всіх рівнів освіти норму, що «ліцензування освітньої діяльності - це процедура визнання спроможності юридичної або фізичної особи надавати освітні послуги на певному рівні освіти відповідно до ліцензійних умов» (ст. 43.1). Це знімає проблеми розробки та змісту стандартів освітньої діяльності, але породжує нові питання [49]:

* у вищій освіті має ліцензуватися діяльність за спеціальністю на певному рівні чи лише діяльність на рівні незалежно від спеціальності;

* якщо обрати перший варіант, то як врахувати специфіку спеціальностей в ліцензійних умовах;

* чи можна вимоги до стандартів освітньої діяльності розглядати як вимоги до ліцензійних умов, що враховують особливості освітньої діяльності;

* наскільки можна доповнити загальні вимоги до ліцензійних умов іншими вимогами, які випливають з особливостей освітньої діяльності?

$€$ також інші питання, породжені суттєвою зміною концепції ліцензування, що теж потребують відповідей:

- $\quad$ хто і як має перевіряти виконання спеціальних вимог, що стосуються спеціальності, за відсутності фахової експертизи;

- $\quad$ якими мають бути формат й обсяг вимог з огляду на нові процедури й строки розгляду заяв на ліцензування?

Ще один комплекс проблем породжується конфліктом між різними цілями та завданнями державного регулювання у сфері вищої освіти [50]. 3 одного боку, воно має забезпечувати якість освіти і запобігати діяльності тих, хто лише імітує iii та надає здобувачам і партнерам неправдиву інформацію про очікувані результати навчання. 3 іншого - в умовах швидких змін, які відбуваються у вищій освіті не тільки України, але і всього світу, ліцензійні умови не повинні гальмувати розвиток і перешкоджати адаптації ЗВО і системи вищої освіти у цілому до цих змін. Насамперед, йдеться про інформатизацію освіти; дуальну освіту; зарахування результатів навчання, отриманих в неформальній та інформальній освіті, у т. ч. через професійну і громадську діяльність; академічну мобільність; спільні програми, створювані декількома 3ВО; створення міждисциплінарних освітніх програм і програм типу liberal arts; залучення практиків до викладання у вищій школі тощо.

Все це не дуже узгоджується з парадигмою, за якою весь освітній процес відбувається в конкретному ЗВО, і вимоги до цього ЗВО дають змогу забезпечити якість освіти. Чи відповідає нова редакція Ліцензійних умов всім зазначеним вимогам? Очевидно, що ні. Їх підготовка тривала близько двох років. Протягом цього часу відбулося два громадські обговорення, де було висловлено багато різних, у тому числі таких, що суперечать одна одній, пропозицій. Був прийнятий 
новий Закон України «Про освіту», ухвалений новий Порядок денний ЄС для вищої освіти, відбулася чергова конференція міністрів освіти країн Європейського освітнього простору, яка поставила нові цілі, що вкотре засвідчили суттєве відставання вищої освіти України від інших європейських країн. Чи варто було відкладати затвердження нових Ліцензійних умов для доопрацювання? Імовірно теж ні, бо попередня редакція не відповідала жодному із законів, які регулюють ліцензування у сфері вищої освіти, і створювала значно більші перешкоди для їі розвитку.

Суттєвою відмінністю нової редакції Ліцензійних умов стало видалення вимог, які стосуються конкретних освітніх програм. Це $є$ важливим кроком у напрямі дерегуляції та виконання вимоги Закону України «Про вищу освіту», відповідно до якої ліцензується освітня діяльність за спеціальністю. Разом з тим, слід зазначити, що ця лінія проведена недостатньо послідовно. Норми про навчальні плани та дисципліни видалені з основного тексту Ліцензійних умов (крім згадки, що мають бути навчальні плани й робочі програми навчальних дисциплін). Але у додатках, що містять форми документів, які має надавати заклад, зберіглася прив'язка інформації, що надається стосовно кадрового, матеріально-технічного, навчально-методичного та інформаційного забезпечення, до конкретних навчальних дисциплін, як це було у попередньому варіанті Ліцензійних умов. Це $є$ не тільки непотрібним, оскільки немає вимог, для перевірки яких потрібна ця інформація. Це ще $є$ вкрай обтяжливим для закладів вищої освіти, що ліцензують освітню діяльність.

У зв'язку із відмовою від вимог до освітніх програм та їх складників у новій редакції Ліцензійних умов суттєво змінено вимоги до кадрового забезпечення. 3'явилися поняття групи забезпечення спеціальності та «кваліфікації відповідно до спеціальності». Позитивно оцінюючи ці новації у цілому, варто зазначити, що їх реалізація потребує доопрацювання.

Перш за все, варто розділити показники, що засвідчують відповідність спеціальності, і показники рівня наукової та професійної активності. Змішування у п. 30 обох груп показників веде до того, що відповідність спеціальності можуть засвідчувати результати роботи не за спеціальністю Приміром, керівництво відділом чи аспірантурою, виконання функцій відповідального секретаря приймальної комісії тощо. 3 іншого боку показниками активності можуть бути результати, отримані $20-30$, а іноді й 50 років тому.

Найближчим аналогом професійної кваліфікації у сфері вищої освіти сьогодні є вчені звання [51, 52]. Але саме їх як підтвердження кваліфікації Ліцензійні умови не зарахували, хоча до цього часу багато років їх визнавали як підтвердження кваліфікації. Головним аргументом для такого рішення була велика кількість документів про вчене звання, виданих особам, які очевидно не мали жодного відношення до спеціальності, крім роботи (іноді тимчасової) на кафедрі з відповідною назвою. На жаль, тут маємо ще одну застарілу, але досі не вирішену проблему чинного законодавства. Незважаючи на те, що звання присвоюють за кафедрою чи спеціальністю, ані чинний, ані попередній від 1997 р. Порядки присвоєння вчених звань серед вимог до здобувачів не містять згадки 
про відповідність наукових і методичних публікацій та інших результатів діяльності кафедрі чи спеціальності, за якою їм присвоюють вчене звання. Разом 3 тим, помилки законодавства не є достатньою підставою для позбавлення кваліфікації тих, хто за рішенням органів державної влади отримав ії відповідно до чинних на момент присвоєння правил. Скоріше, вони мають стати підставою для виправлення цих помилок. 3 іншого боку, підтвердження кваліфікації лише документами про освіту чи науковий ступень, іноді виданими декілька десятирічь тому, теж $\epsilon$ не зовсім коректним. В сучасному суспільстві напрями діяльності багатьох людей змінюються впродовж життя не однократно. Крім того, відповідно до змін, що відбуваються у законодавстві, документи про освіту, а невдовзі і про ступень доктора філософії, перетворюватимуться на посвідчення освітньої, а не професійної кваліфікації. Втім, раніше видані документи певною мірою (іноді й безпосередньо) засвідчували також і професійну кваліфікацію. Тому повністю відмовлятися від них як свідчення професійної кваліфікації сьогодні було б неправильно. Але вважати таким свідченням ці документи, незалежно від часу їх отримання, теж буде помилкою. Крім того, практика останніх двох десятиріч, коли при ліцензуванні та акредитації в тому чи іншому вигляді застосовували вимоги до формальної освіти, свідчить, що в наших умовах це лише стимулює отримання науково-педагогічними працівниками додаткових дипломів про вищу освіту та/або наукових ступенів. Щоб на будь-які вимоги МОН України в них знайшовся потрібний диплом.

Як варіант вирішення проблеми можна було б запропонувати використовувати для підтвердження кваліфікації відповідно до спеціальності два альтернативні блоки вимог:

- наявність документа про вищу освіту, науковий ступень та вчене звання, що відповідають спеціальності, і які отримані не більш, ніж 5 - 10 років тому;

- наявність протягом останніх $5-10$ років серйозних професійних результатів діяльності зі спеціальності (наукові статті у провідних наукових виданнях, що індексуються у визнаних наукометричних базах, монографії, підручники, навчальні посібники, винаходи 3 підтвердженим великим економічним ефектом, творчі досягнення для мистецьких спеціальностей).

Також для сприяння розвитку ЗВО варто було б повернути до Ліцензійних умов норму, за якою для цілей ліцензування зараховуються не лише науковопедагогічні і наукові працівники, що мають кваліфікацію відповідно до спеціальності, але і ті, хто має аналогічну кваліфікацію зі споріднених спеціальностей [53].

Також слід зазначити, що поки не усунуто основні бар'єри, що заважають розвитку інклюзивної освіти, проблему оптимізації Ліцензійних умов не вдасться вирішити [54] . Але не треба забувати, що саме від нас залежить майбутнє сьогоднішніх дітей-студентів вишів i те, наскільки вони будуть корисні суспільству і державі надалі. Адже тільки люди з гарною вищою освітою можуть сприяти прогресу у сфері охорони здоров'я і фармацевтичній галузі й процвітанню держави. А дати гарну вищу освіту саме дітям (малолітніх/неповнолітніх)-молоді-студентам 3 обмеженими можливостями 
допоможе інклюзивна освіта, головним діючим фактором у якій є обгрунтований та результативний медико-психологічний та юридичний супровід освітнього процесу під час забезпечення Ліцензійних умов у системі правовідносин «лікар - діти/студенти з обмеженими можливостями здоров'я - психолог - педагог професорсько-викладацький склад 3ВО- адвокат» [55].

Виконання Ліцензійних умов, щодо якості освіти у ЗВО сприятиме сучасному рівню підготовки лікарів, провізорів та юристів та забезпечення права громадян (пацієнтів) на доступ до якісної, ефективної, безпечної, своєчасної медичної допомоги та забезпечення життєво необхідними ліками [56-61]. Вказана концепція надалі повинна бути використана як основа для підготовки проектів внесення змін до чинного законодавства в сфері підготовки кадрів.

Висновки. Здійснено організаційно-правове вивчення 3 метою виконання адміністративним персоналом вузів ліцензійних умов і нормативно-правових актів щодо провадження освітньої діяльності в Україні під час пандемії на COVID-19. Обгрунтовано про необхідність подальшого вдосконалення системи ліцензування освітньої діяльності. Зазначено про доцільність збереження ліцензування освітньої діяльності для кожної спеціальності на кожному рівні вищої освіти та переходу до ліцензування освітньої діяльності лише за рівнями. Запропоновано про альтернативу створення окремих вимог для кожної спеціальності, що більше відповідає чинному Закону про вищу освіту. Але це проблематично з погляду можливості реалізації та, очевидно, суперечить курсу на дерегуляцію, і практикам, що існують в Свропейському просторі вищої освіти. Ще однією альтернативою $є$ перехід до ліцензування освітньої діяльності за галузями знань. На більш (але не дуже) віддалену перспективу потрібно вирішувати більш концептуальні питання: де пролягає межа доцільного втручання держави у діяльність ЗВО; що саме треба ліцензувати; які вимоги можуть бути корисними, а які лише перешкоджатимуть розвитку закладів вищої освіти. Подальші організаційно-правові дослідження щодо виконання адміністративним персоналом вишів ліцензійних умов і нормативно-правових актів для провадження освітньої діяльності в Україні під час пандемії на COVID19 тривають.

Конфлікт інтересів. Автори повідомляють про відсутність конфлікту інтересів.

\section{Література.}

1. Наказ Міністерство охорони здоров'я України від 24.12.2020 № 3018 «Про затвердження Дорожньої карти 3 впровадження вакцини від гострої респіраторної хвороби COVID-19, спричиненої коронавірусом SARS-CoV-2, i проведення масової вакцинації у відповідь на пандемію COVID-19 в Україні у 2021 - 2022 роках» \{Із змінами, внесеними згідно з Наказами Міністерства охорони здоров'я № 213 від 09.02.2021; № 369 від 01.03.2021; № 443 від 11.03.2021; № 745 від 16.04.2021; № 927 від 13.05.2021; № 1423 від 12.07.2021; № 2362 від 27.10.2021\}. Zakon Online. 27.10.2021. URL: https://zakononline.com.ua/documents/show/492031_682000 
2. Становлення публічного адміністрування в Україні: матеріали IX Всеукр. міжвуз. конф. студентів та молодих учених / За заг. ред. О. Б. Кірєєвої. Д.: ДРІДУ НАДУ, 2018.

$213 \mathrm{c}$.

URL: http://www.dridu.dp.ua/konf/konf_dridu/2018_04_27_fsdu_stud.pdf

3. Прес-служба ОДА. Від сьогодні вступили в силу нові карантинні обмеження для невакцинованих громадян - роз'яснення МОЗ. Львівська обласна державна адміністрація. 06.12.2021. URL: https://loda.gov.ua/news?id=64048

4. Shapovalov Valentyn, Butko L., Shapovalov V. Organizational and legal study of quarantine restrictions in the spread of coronavirus disease in Ukraine. SSP Modern Pharmacy and Medicine. 2021. Vol. 1. N. 2. P. 1-12. URL: https://doi.org/10.53933/sspmpm.v1i2.23

5. Медична реформа. Урядовий портал. Червень 2020. URL: https://www.kmu.gov.ua/diyalnist/reformi/rozvitok-lyudskogo-kapitalu/reformasistemi-ohoroni-zdorovya

6. Hayduchok I., Shapovalov V. COVID-19: multidisciplinary researches of forensic and pharmaceutical risks and causal relationships of unqualified medical care for patients during pandemic. 2022. SSP Modern Law and Practice. Vol.2. N.1. P.1-25. URL: https://doi.org/10.53933/sspmlp.v2i1.39 (In Ukrainian)

7. Клімов О. Аптечна справа в Україні - 30 років еволюції чи 30 років руйнації? Всеукраїнська фармацевтична палата. 06.02.2022. URL: http://farmpalata.com.ua/novyny/aptechna-sprava-v-ukrayini-30-rokiv-evolyutsiyichy-30-rokiv-rujnatsiyi/

8. Нові правила у фармації: що маємо на сьогодні та чого очікувати? Apteka.ua. 24.01.2022. №02 (1323). URL: https://www.apteka.ua/article/625670

9. Лур'є Д. На яку державну політику очікувати у фармацевтичній сфері? EBA. 02. 10.2021. URL: https://eba.com.ua/na-yaku-derzhavnu-polityku-ochikuvatyu-farmatsevtychnij-sferi/

10. Імунізація. Центр Громадського здоровья MO3 України. 06.02.2022. URL: https://phc.org.ua/kontrol-zakhvoryuvan/imunizaciya/zagalna-informaciya

11. Часті питання (FAQ). MO3 України. 01.02.2022. URL: https://covid19.gov.ua/chasti-pytannia-faq

12. Що нового у сфері охорони здоров'я. Довідник головної медичної сестри. 05.02.2022. URL: https://emedsestra.mcfr.ua/rssnews

13. Zbrozgek S. Reform of the healthcare system as a basis for streamlining the organization of circulation and availability of medicines for patients in the context of the COVID-19 pandemic. SSP Modern Pharmacy and Medicine. 2021. Vol. 1. No. 2. P. 1-32. URL: https://doi.org/10.53933/sspmpm.v1i2.31 (In Ukrainian)

14. Гнатюк Л.С., Черкашина А.В. Дослідження сучасного стану фармацевтичного забезпечення хворих на коронавірусну інфекцію Covid-19 в Україні. Сучасні напрямки удосконалення фармацевтичного забезпечення населення: від розробки до використання лікарських засобів природного i синтетичного походження: матеріали науково-практичної дистанційної міжнародної конференції, м. Івано-Франківськ, 19-20 травня 2020 р. ІваноФранківськ: IФНМУ, 2020.2 C.20-23 URL: 
https://www.ifnmu.edu.ua/images/diyalnist_universitetu/konferencii/2020/materiali_u doskonalen.pdf

15. Указ Президента України «Про рішення Ради національної безпеки i оборони України від 30 липня 2021 року "Про стан національної системи охорони здоров'я та невідкладні заходи щодо забезпечення громадян України медичною допомогою". 19.08.2021. URL: https://zakon.rada.gov.ua/laws/show/369/2021\#n5

16. Shapovalova V. The ICD-11 for the twenty-first century: the first view from the organizational, legal, clinical and pharmacological aspects. SSP Modern Pharmacy and Medicine. 2022. Vol.2. N.1. P.1-13. URL: https://doi.org/10.53933/sspmpm.v2i1.37

17. Shapovalova V.O., Zbrozhek S.I., Shapovalov V.V., Shapovalov V.V. Coronavirus disease pandemia 2019: growth of epidemic dangers. Acta scientific pharmaceutical sciences. 2020. Vol.4. Iss.7. P.61-68. URL: https://doi.org/10.31080/ASPS.2020.04.0559

18. Шаповалова В.О. Фармацевтическое и медицинское право: гарант юридической опеки врача, провизора, пациента. Apteka.ua. 24 червня 2011. URL: https://www.apteka.ua/article/86163

19. Shapovalova V., Zakharchenko I. Organizational and legal approaches to reforming of the law enforcement system of Ukraine: illegal circulation of psychoactive substances and addictive dependence. 2021. SSP Modern Law and Practice. Vol. 1. N.1. P.1-22. URL: https://doi.org/10.53933/sspmlp.v1i1.20 (In Ukrainian)

20. Гайдучок І.Г., Шаповалов В.В. Судова фармація та медицина: ризики для фармакотерапії адиктивної залежності та протидії незаконного обігу психоактивних речовин в умовах пандемії Covid-19. SSP Modern Pharmacy and Medicine. 2021. Vol.1. N.2. P.1-28. URL: https://ssp.ee/index.php/mpm/article/view/32/29

21. Shapovalov (Jr.) V., Gudzenko A., Komar L. et al. Concerning the importance of forensic and pharmaceutical researches to improve patients' accessibility to medicines. Pharmacia. 2017. Vol. 65. N. 2. P. 23-29. URL: http://bsphs.org/wpcontent/uploads/2017/07/Shapovalov.pdf.

22. Шаповалова В.О. Провизоры, юристы и врачи объединяются для развития фармацевтического права. Apteka.ua. 04.12.2006. № 47 (568). URL: https://www.apteka.ua/article/4038

23. Шаповалова В.О., Сосін І.К., Шаповалов В.В. Фармацевтичне право: за підсумками конференцій. Apteca.ua. 11.12.2006. № 48 (569). URL: https://www.apteka.ua/article/4098

24. Shapovalova V. A., Datkhayev U. M., Shapovalov V. V. (Jr.) et al. Introduction to pharmaceutical law and forensic pharmacy. The Third International scientific congress of scientists of Europe. Proceedings of the III International Scientific Forum of Scientists "East-West" (January 11, 2019). Premier Publishing s.r.o. Vienna. 2019. P. 43-49.

25. Shapovalov V.V. (Jr.), Zbrozhek S.I., Shapovalova V.O., Shapovalov V.V. Organizational and legal evaluation of availability of medicines' circulation for cancer patients. Pharmacia. 2018. Vol.65, N.2. P.17-22. URL: 
http://bsphs.org/?magasine=organizational-and-legal-evaluation-of-availability-ofmedicines-circulation-for-cancer-patients.

26. Shapovalov (Jr.) V., Gudzenko A., Shapovalova V. et al. Forensic and pharmaceutical study of the presence of a causal link between the degree of alcohol abuse and qualification level of the respondents. Pharmacia. 2017. Vol. 66. N. 3. P.3139. URL: http://bsphs.org/wp-content/uploads/2017/11/Shapovalov.pdf.

27. Оперативна інформація про поширення та профілактику COVID-19. MO3 України. 06.02.2022. URL: https://moz.gov.ua/article/news/operativna-informacijapro-poshirennja-koronavirusnoi-infekcii-2019-cov19

28. Вакцинація від коронавірусу в Україні. Мінфін. 05.02.2022. URL: https://index.minfin.com.ua/ua/reference/coronavirus/vaccination/ukraine/

29. Бабічева О. Комплекс маркетингу вищого навчального закладу. Ринок освітніх послуг: виклики сучасності. Збірник матеріалів науково-практичної конференції з міжнародною участю (м. Київ, 11 червня 2019 р.) Київ: АПСВТ, 2019. C.9-10 https://www.socosvita.kiev.ua/sites/default/files/Tezy_Conf_11_06.pdf

30. Волох Л. Переваги та недоліки дистанційної освіти у ЗВО // Ринок освітніх послуг: виклики сучасності: Збірник матеріалів науково-практичної конференції 3 міжнародною участю (м. Київ, 11 червня 2019 р.). Київ: АПСВТ, 2019. С. 17-19. URL: https://www.socosvita.kiev.ua/sites/default/files/Tezy Conf 11 06.pdf

31. Коваленко С. Окремі аспекти державного регулювання ринку освітніх послуг в Україні. Ринок освітніх послуг: виклики сучасності. Збірник матеріалів науково-практичної конференції з міжнародною участю (м. Київ, 11 червня 2019 р.). Київ: АПСВТ, 2019. С. 36-37

32. Шевченко О.Т., Василенко I.О., Чубенко В.А. Інформаційні технології у медицині: практика впровадження у черкаській медичній академії та підготовка фахівців. Актуальні проблеми методології вищої медичної (фармацевтичної) освіти: сучасні виклики та нові можливості. Матеріали Всеукраїнської науковометодичної інтернет-конференції, присвяченої 90-річчю Черкаської медичної академії, м. Черкаси, 15 жовтня 2020 р. Черкаси: Видавець О. Вовчок, 2020. С.81$84 . \quad$ URL:

content/uploads/2020/10/Conference content.pdf

http://medcollege.ck.ua/wp-

33. Корчинська О. Наукова дискусія про ринок освітніх послуг. Ринок освітніх послуг: виклики сучасності. Збірник матеріалів науково-практичної конференції 3 міжнародною участю (м. Київ, 11 червня 2019 р.) Київ: АПСВТ, 2019. 98 с. URL: https://mon.gov.ua/storage/app/media/nrk/Analitychni-materialy/7-natsionalnadopovid-pro-stan-i-rozvitok-osviti-v-ukraini.pdf

34. Національна доповідь про стан і перспективи розвитку освіти в Україні / За заг. ред. В. Г. Кременя. Київ: Педагогічна думка, 2016. 448 с.

35. Шахно А.Ю. Моделі розвитку та державне регулювання людського капіталу в умовах глобалізації. Кваліфікаційна наукова праця на правах рукопису. Дисертація на здобуття наукового ступеня доктора економічних наук за спеціальністю 08.00.03 - економіка та управління національним господарством. Національний університет «Львівська політехніка» Міністерства освіти і науки України, Львів, 2019. 561 с. 
https://pnu.ua/sites/default/files/2020/dissertation/1318/dysertaciyashahnoayu.pdf 36. Майбутнє університетів. Український інститут майбутнього. 08.03.2020. URL: $\quad$ https://uifuture.org/publications/majbutnye-universitetiv/; https://www.socosvita.kiev.ua/sites/default/files/Tezy_Conf_11_06.pdf

37. Річний звіт Національного агентства із забезпечення якості вищої освіти за 2019 рік / За заг. ред. проф. Сергія Квіта. Київ: Національне агентство із забезпечення якості вищої освіти, 2020. 244c. URL: https://naqa.gov.ua/wpcontent/uploads/2020/02/\%D0\%97\%D0\%B2\%D1\%96\%D1\% $\underline{82-2020 . p d f}$

38. Зіменковський Б.С., Гжегоцький М.Р., Солонинко I.І. Управління якістю підготовки лікарів і провізорів в умовах кредитно-модульної системи. Впровадження нових технологій за кредитно-модульної системи організації навчального процесу у ВМ(Ф)НЗ III-IV рівнів акредитації. Матеріали Всеукр. наук. навч.-метод. конф., присвяченої 55-річчю Тернопільського державного медичного університету (Тернопіль, 26-27 трав. 2012 р.). Тернопіль: ТДМУ, 2012. - $\quad$ C.75-76. URL: https://repo.dma.dp.ua/465/1/\%D0\%97\%D0\%B1 \%D1\%80\%D0\%BD\%D0\%B8\%D 0\%BAKMC 04 26.pdf

39. Зіменковський Б.С. Вітальне слово. Здобутки та перспективи управління фармацевтичною системою. Збірник праць науково-практичної конференції 3 міжнародною участю, присвяченої 90-річчю 3 дня народження професора Р. М. Піняжка і 75-річчю $з$ дня народження професора О. Л. Грома (м. Львів, $28-29$ вересня 2018 р.). Львів: Ліга-Прес, 2018. C.6-7. URL: https://new.meduniv.lviv.ua/uploads/repository/kaf/kaf_organizationpharm/04.\%D0\% 9D\%D0\%B0\%D1\%83\%D0\%BA\%D0\%BE\%D0\%B2\%D0\%B0 \%D0\%B4\%D1\%96 \%D1\%8F\%D0\%BB\%D1\%8C\%D0\%BD\%D1\%96\%D1\%81\%D1\%82\%D1\%8C/Zbir nyk \%20tez \%20konfer \%20OEF \%202018 \%20Zdobutky \%20ta \%20perspekty vy.pdf

40. Підготовка медичних та фармацевтичних кадрів: що пропонують народні депутати? Apteka.ua. 24.01.2022. URL: https://www.apteka.ua/article/625595

41. Закон України від 19.11.1992 р. № 2801-XII «Основи законодавства України про охорону здоров'я» доповнюватиметься новими термінами, такими як «база стажування лікарів (провізорів)-інтернів», «лікар (провізор)-інтерн», «лікаррезидент».

42. Преамбула Закону України від 12.01.2012 р. № 4312-VI «Про професійний розвиток працівників» уточнюватиметься стосовно особливостей професійного розвитку окремих категорій працівників, які можуть визначатися спеціальними законами.

43. Про затвердження Ліцензійних умов провадження освітньої діяльності. Постанова КМУ від 30 грудня 2015 p. № $1187 . \quad$ URL: https://zakon.rada.gov.ua/laws/show/1187-2015-п\#Text

44. Про ліцензування видів господарської діяльності. Закон України. URL: http://zakon5.rada.gov.ua/laws/show/222-19.

45. Shapovalov V.V., Shapovalova V.O., Shapovalov V.V. et al. Medychne ta 
farmatsevtychne pravo: navch. posib. dlia dodyplomnoi ta pisliadyplomnoi formy navchannia. Seriia «Medychne ta farmatsevtychne pravo». 4-e vyd. zi zminamy ta dopovnenniamy. Kharkiv - Ivano-Frankivsk: KhMAPO, 2020. $128 \mathrm{~s}$.

46. Shapovalova V. The ICD-11 for the twenty-first century: the first view from the organizational, legal, clinical and pharmacological aspects. SSP Modern Pharmacy and Medicine. 2022. Vol.2. N.1. P.1-13. URL: https://doi.org/10.53933/sspmpm.v2i1.37

47. Hayduchok I., Shapovalov B. Covid-19: multidisciplinary researches of forensic and pharmaceutical risks and causal relationships of unqualified medical care for patients during pandemic. 2022. SSP Modern Law and Practice. Vol.2. N.1. P.1-25. URL: https://doi.org/10.53933/sspmlp.v2i1.39

48. Про освіту. Закон України. URL: http://zakon3.rada.gov.ua/laws/show/2145$\underline{19}$.

49 .

Новини

вищої

освіти.

URL:

https://www.facebook.com/groups/284339708674108/permalink/469024353538975

50. Про вищу освіту. Закон

URL: http://zakon3.rada.gov.ua/laws/show/1556-18.

51. Порядок присвоєння вчених звань науковим і науково-педагогічним працівникам. URL: http://zakon5.rada.gov.ua/laws/show/z0183-16

52. Порядок розгляду атестаційних справ науково-педагогічних працівників про присвоєння вчених звань професора i доцента. URL: http://zakon5.rada.gov.ua/laws/show/z0616-97/ed19971113.

53. Бахрушин В. Проблеми ліцензування освітньої діяльності у вищій освіті. 2018. URL: http://education-ua.org/ua/articles/1221-problemi-litsenzuvannyaosvitnoji-diyalnosti-u-vishchij-osviti

54. Бровченко А.К., Шаповалова В.О., Шаповалов Валентин В. Підгрунтя та проблеми медико-психологічного та юридичного супроводу в інклюзивній освіті. Педагогіка здоров'я. Збірник наукових праць IX Всеукраїнської науковопрактичної конференції «Педагогіка здоров'я» (м. Чернігів, 27-28 вересня 2019 р.). Чернігів, 2019. С. 268-272

55. Шаповалов В.В. (мол.). Юридична опіка в системі правовідносин «лікар пацієнт - провізор» на засадах медичного і фармацевтичного права. Управління закладом охорони здоров’я. 2012. № 9. С. 29-37.

56. Шаповалова В., Шаповалов Валентин, Шаповалов В. та інш. Викладання медичного і фармацевтичного права в системі післядипломної освіти лікарів $\mathrm{i}$ провізорів. Здобутки та перспективи управління фармацевтичною системою. Збірник праць науково-практичної конференції 3 міжнародною участю, присвяченої 90-річчю з дня народження професора Р. М. Піняжка і 75-річчю 3 дня народження професора О. Л. Грома (м. Львів, 28 - 29 вересня 2018 р.). Львів: Ліга-Прес, $2018 . \quad$ C.156-160. URL: https://new.meduniv.lviv.ua/uploads/repository/kaf/kaf organizationpharm/04.\%D0\% 9D\%D0\%B0\%D1\%83\%D0\%BA\%D0\%BE\%D0\%B2\%D0\%B0 \%D0\%B4\%D1\%96 \%D1\%8F\%D0\%BB\%D1\%8C\%D0\%BD\%D1\%96\%D1\%81\%D1\%82\%D1\%8C/Zbir nyk \%20tez_\%20konfer_\%20OEF_\%202018_\%20Zdobutky_\%20ta_\%20perspekty vy.pdf 
57. Shapovalov V.V. (Jr.), Shapovalova V.A., Shapovalov V.V. Development of forensic and pharmaceutical researches within the organization of pharmaceutical business, drug technology and pharmaceutical law in Ukraine concerning the turnover of controlled drugs and substances. Health of Society. 2021. Vol. 10. N. 3. P. 98-106. doi:https://doi.org/10.22141/2306-2436.10.3.2021.246351 (In Ukrainian)

58. Shapovalov V.V. (Jr.), Shapovalova V.A., Shapovalov V.V. Forensic and pharmaceutical research on the impact of drugs on the safety, life and health of road users within the organization of pharmaceutical business, drug technology, pharmaceutical and medical law in Ukraine. Health of Society. 2021. Vol. 10. N. 4. P. 127-132. doi: https://doi.org/10.22141/2306-2436.10.4.2021.246355 (In Ukrainian) 59. Shapovalova V., Zakharchenko I. Organizational and legal approaches to reforming of the law enforcement system of Ukraine: illegal circulation of psychoactive substances and addictive dependence. 2021. SSP Modern Law and Practice. Vol. 1. N.1. P.1-22. URL: https://doi.org/10.53933/sspmlp.v1i1.20 (In Ukrainian).

60. Chuiev Y., Shapovalova V. Integrated ABC/VEN-analysis of drug prescriptions in pharmacotherapeutic schemes for relief of drunken forms of alcohol dependence. SSP Modern Pharmacy and Medicine. 2022. Vol.2. N.1. P.1-14. URL: https://doi.org/10.53933/sspmpm.v2i1.35

61. Chuiev Y., Shapovalova V. Interdisciplinary pharmacoeconomic study of pharmacotherapy of cupping of drunk forms of alcohol dependence: clinical and pharmacological, organizational, legal and marketing experiment. SSP Modern Pharmacy and Medicine. 2021. Vol.1. N. 2. P. 1-12. URL: https://doi.org/10.53933/sspmpm.v1i2.24 (In Ukrainian) 